\title{
Wspomnienie o Profesorze Andrzeju Wyrobiszu
}

15 października 2018 r. zmarł Profesor dr hab. Andrzej Wyrobisz.

Profesor urodził się w 1931 r. w Krakowie, jednak w Warszawie studiował historię na Uniwersytecie Warszawskim i w stolicy zdobył kolejne stopnie prowadzące go do tytułu profesora. Był uczniem wybitnego mediewisty, Profesora Mariana Małowista. Szkole tego profesora zawdzięczał (co niejednokrotnie podkreślał) wszechstronną wiedzę z epoki średniowiecza polskiego i powszechnego, ale także umiejętności warsztatowe, wnikliwe badanie źródeł, wagę kontekstu ich powstania, umiejętności analityczne i syntetyczne, sprawność w zadawaniu pytań, tworzenia hipotez i wyciągania wniosków z badania.

Szkoła Profesora Mariana Małowista przygotowała Profesora Andrzeja Wyrobisza do rozszerzenia chronologicznego badań, wejścia w kwerendy źródłowe z epoki nowożytnej i tematycznego wzbogacenia poszukiwań badawczych. Oprócz kręgów historii polskiej i powszechnej średniowiecza i historii nowożytnej, Profesor doskonale poruszał się w dziedzinie historii sztuki. Rzecz znamienna, iż od początku Jego zainteresowań sztuką, widział ją w szerokim, historycznym, a więc i chronologicznym kontekście. Nie unikał przy tym porównań procesów zachodzących w sztuce państwa polsko-litewskiego z tendencjami w rozwoju sztuki zachodnioeuropejskiej.

Droga naukowa Profesora była odbiciem rozszerzania się kręgu Jego zainteresowań. W 1955 r. skończył studia magisterskie, których uwieńczeniem była praca dotycząca rzemiosła paryskiego w XV w. W sześć lat później (w 1961 r.) obronił doktorat $\mathrm{w}$ Instytucie Historii Kultury Materialnej PAN na podstawie pracy Budownictwo murowane $w$ Małopolsce $w X I V-X V$ wieku. Praca ta była pisana pod kierunkiem naukowym profesora Mariana Małowista. Książka habilitacyjna na temat: Szkło w Polsce od XIV do XVII wieku i artykuły stanowiące dorobek Profesora stały się podstawą do uzyskania stopnia doktora habilitowanego w 1968 r., także w Instytucie Historii Kultury Materialnej PAN. Od 1978 r. - profesor nadzwyczajny, od 1995 r. - profesor zwyczajny. Od 1969 r. Profesor pracował na Wydziale Historycznym Uniwersytetu Warszawskiego. 
W latach 1962-1967 był kierownikiem Ekspedycji Wykopaliskowej w Solcu nad Wisłą zorganizowanej przez IH KM PAN.

W 1969 r. Profesor Andrzej Wyrobisz podjął się misji tworzenia podstaw do powstania humanistyki w Wyższej Szkole Nauczycielskiej przekształconej w Filię UW w Białymstoku. Było to zadanie niezwykle trudne zważywszy, iż na ,ścianie wschodniej" poza uniwersytetami lubelskimi (UMCS i KUL) nie było żadnej uczelni humanistycznej. Nie było biblioteki z prawdziwego zdarzenia, były kłopoty z pozyskaniem odpowiedniej kadry. Działalność Profesora poszła w kilku kierunkach: gromadzenie zbiorów bibliotecznych, zatrudnianie kadry (w pierwszym okresie trwania Filii pozyskiwanie do pracy w Białymstoku pracowników z Warszawy) i kształcenie młodzieży na dwóch kierunkach: Filologii Polskiej i Historii. Do Białegostoku na zajęcia dojeżdżali z Warszawy w tym okresie, m.in. Profesorowie: Ewa Wipszycka, Elżbieta Kaczyńska, Andrzej Makowiecki, Jerzy Bralczyk, Bronisław Nowak. Profesor Wyrobisz był inicjatorem wykładów otwartych prowadzonych przez osoby z zewnątrz. W ten sposób Filia UW w Białymstoku gościła w pierwszym okresie swego trwania m.in. Profesorów: Aleksandra Gieysztora, Benedykta Zientarę, Henryka Samsonowicza, Antoniego Mączaka.

Szczególne znaczenie miała tworzona Biblioteka Humanistyczna. Zakupy antykwaryczne i zdobywanie nowości wydawniczych były priorytetem $\mathrm{w}$ tej działalności Profesora. Mimo ogromnych problemów finansowych pozyskano wówczas podstawowe podręczniki akademickie, wydawnictwa źródłowe z XIX i XX w., monografie. Umożliwiało to kształcenie i przygotowywanie prac dyplomowych. Zbiory te obecnie znajdują się w Kolekcji Humanistycznej Biblioteki Uniwersyteckiej im. J. Giedroycia w Białymstoku. Troska o zbiory biblioteczne w Białymstoku towarzyszyła Profesorowi do końca życia. Część jego własnych zbiorów znalazła się zgodnie z Jego wolą w Bibliotece Wydziału Historyczno-Socjologicznego UwB w Białymstoku.

Profesor prowadził w Filii UW w Białymstoku seminaria, na początku na poziomie licencjatu. Część Jego uczniów po ukończeniu Wyższej Szkoły Nauczycielskiej, przekształconej w Filię UW, kontynuowała dalszą edukację w Uniwersytecie Warszawskim, kształcąc się na poziomie studiów 5-letnich.

Profesor Wyrobisz był zaangażowany w administrację Instytutu Historii i Wydziału Humanistycznego Filii UW w Białymstoku od 1969 do 1985 r., pełniąc funkcje: kierownika Zakładu, dyrektora Instytutu Historii i dziekana Wydziału Humanistycznego.

Chcę podkreślić, iż Profesor Andrzej Wyrobisz był bez wątpienia twórcą humanistyki białostockiej, nie odbierając chwały i doceniając kontynuatorów Jego dzieła - Profesorów: Teresy Monasterskiej, Mieczysława Wrzoska, Andrzeja Wyczańskiego i Barbary Holzerowej.

Profesor od 1969 do 1996 r. pracował jednocześnie w Instytucie Historycznym Uniwersytetu Warszawskiego, od 1996 r. w Instytucie Historii Sztuki. 
Pracował w tym Instytucie także jako wolontariusz po przejściu na emeryturę. Dopiero choroba położyła kres jego aktywności dydaktycznej.

Profesor był visiting professor w University of Illinois, Urbana - Champaigne 1976 oraz University of Notre Dame 1989-1990. Staże zagraniczne odbył w École Practique des Hautes Études w Paryżu 1959-1960, w Fondazione Giorgio Cini w Wenecji 1963, w Darwin College w Cambridge 1988. Był członkiem zwyczajnym Towarzystwa Naukowego Warszawskiego, członkiem honorowym Polskiego Towarzystwa Historycznego, członkiem-założycielem Polskiego Towarzystwa Naukowego AIDS.

Opublikował około 450 prac naukowych i popularnonaukowych.

Był prawym, uczciwym człowiekiem, niezwykle lojalnym wobec swoich przyjaciół i uczniów.

Dla mnie, uczennicy Profesora, jest wzorem nauczyciela, uczonego obdarzonego pasją badawczą, z przyjemnością odkrywającego mroki historii. Człowieka badającego przeszłość nie dla stopni, sławy, władzy, lecz dla wzbogacania wiedzy własnej i innych, a także dla rozwoju własnej osobowości.

Ewa Dubas-Urwanowicz 